\title{
On the possible increasing of efficiency of ship power plant with the system combined of marine diesel engine, gas turbine and steam turbine, at the main engine - steam turbine mode of cooperation
}

\author{
Marek Dzida, Assoc. Prof. \\ Gdansk University of Technology
}

ABSTRACT

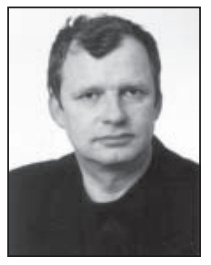

This paper presents a concept of a ship combined high-power system consisted of main piston engine and associated with it: gas power turbine and steam turbine subsystems, which make use of energy contained in exhaust gas from main piston engine. The combined system consisted of a piston combustion engine and an associated with it steam turbine subsystem, was considered. An algorithm and results of calculations of the particular subsystems, i.e. of piston combustion engine and steam turbine, are presented. Assumptions and limitations taken for calculations, as well as comparison of values of some parameters of the system and results of experimental investigations available from the literature sources, are also given. The system's energy optimization was performed from the thermodynamic point of view only. Any technical-economical analyses were not carried out. Numerical calculations were performed for a Wärtsilä slow-speed diesel engine of $52 \mathrm{MW}$ output power.

Keywords: combined systems, gas turbine, piston combustion engine, ship power plants, steam turbine

\section{INTRODUCTION}

For many years in domestic economy a trend to increase efficiency of both land and ship power systems has been developed. It is connected with economic problems (increasing fuel prices) and ecological ones (the lower fuel consumption the lower emission of noxious substances to atmosphere). New solutions are searched for to increase efficiency of power system by joining high-pressure combustion engines with other thermal engines, such as gas and steam turbines, into combined systems.

In recent years combined power systems such as gas - steam turbine systems have been applied to ship power plants. Such systems in land solutions are capable of achieving the efficiency of more than $60 \%$. In a ship solution such system was used on the passenger liner Millenium. However it has been so far an isolated example of the power system of the highest efficiency. The system requires to be supplied with a more expensive fuel oil, i.e. diesel oil (Marine Diesel Oil). Majority of merchant ships is driven by slow-speed diesel engines which combust a relatively inexpensive heavy fuel oil (Heavy Fuel Oil). It seems that such tendency will be still continued for many years in the world merchant fleet.

High-pressure combustion engine (self-ignition one) is still the basic one used as a ship main engine, as on one hand it combusts the most inexpensive fuel oil (heavy oil), and on the other hand it has the highest efficiency as compared with all other heat engines. In exhaust gas from diesel engine is contained a huge amount of energy which can be utilized in another device (engine), that results in increasing the system's efficiency and lowering emission of noxious substances to the atmosphere.

One of such solutions represents a combined cycle of piston combustion engine and gas and steam turbines which utilize waste heat contained in exhaust gas from diesel engine. The piston combustion engine is the leading device in such system. It seems that now when fast containerships of $8 \div 12$ thousand TU capacity enter to service their propulsion systems require engines of a very large output power, of over $50 \div 80 \mathrm{MW}$. On the other hand marine fuel oil is more and more expensive, and restrictive ecological limits for $\mathrm{NO}_{x}$ and $\mathrm{CO}_{2}$ emission to the atmosphere shall force to apply new power system's solutions capable of increasing propulsion efficiency and lowering noxious gas emission to the atmosphere.

For ship main propulsion large slow-speed marine diesel engines working on heavy fuel oil will be still used as their efficiency reaches today $48 \div 51 \%$. At such large unit output values a huge amount of heat contained in exhaust gas and possible to be further utilized, is emitted from the engines.

This paper presents a concept of a combined ship power plant fitted with a main slow-speed, piston combustion engine, as a leading one, and a steam turbine subsystem which utilizes waste heat from exhaust gas. 


\section{A CONCEPT OF COMBINED SHIP POWER SYSTEM}

The assumed combined power system for large containership, having main slow-speed diesel engine and gas and steam turbines which utilize waste heat from the engine's exhaust gas, is shown in Fig. 1.

Exhaust gas discharged from particular cylinders of the main engine is gathered in the exhaust gas collector to supply the constant-pressure turbocharger. For the reason of high efficiency of turbochargers $[1,6]$, the power required for compression of supercharging air is achieved only from a part of exhaust gas flux. The remaining gas flux from the exhaust gas collector can be decompressed in an additional gas turbine, i.e. power turbine. In further considerations it was assumed that the power gas turbine drives additionally - through reduction gear - ship's screw propeller.

Exhaust gas from the turbocharger and power gas turbine flows to the waste heat boiler installed before the silencer in the main engine's exhaust pipeline. The waste heat boiler produces steam used both for driving the steam turbine which delivers its power to the screw propeller, and for ship's overall purposes.

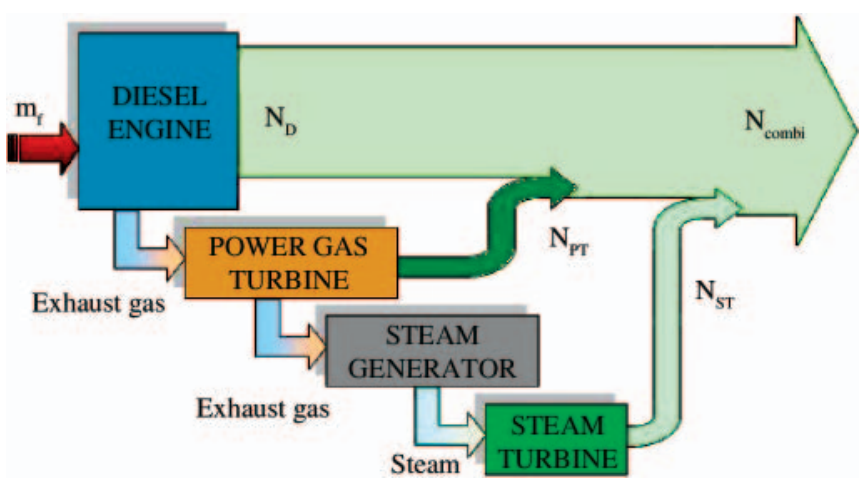

Fig. 1. A concept of combined ship power system

\section{Energy assessment of the combined ship power system}

The proposed concept of combined ship power system should be subjected to assessment of energy of its cycle. On the basis of the assumed schematic diagram shown Fig. 1, formulas for determining the power system's efficiency, were elaborated.

The power of the combined power system is determined by summing up power values of the system's particular components (main engine, power gas turbine and steam turbine):

$$
\mathrm{N}_{\text {combi }}=\mathrm{N}_{\mathrm{D}}+\mathrm{N}_{\mathrm{PT}}+\mathrm{N}_{\mathrm{ST}}
$$

hence the combined system's efficiency is equal to:

$$
\eta_{\text {combi }}=\frac{\mathrm{N}_{\text {combi }}}{m_{\mathrm{fD}} \cdot \mathrm{Wu}}=\eta_{\mathrm{D}} \cdot\left(1+\frac{\mathrm{N}_{\mathrm{PT}}}{\mathrm{N}_{\mathrm{D}}}+\frac{\mathrm{N}_{\mathrm{ST}}}{\mathrm{N}_{\mathrm{D}}}\right)
$$

and the specific fuel oil consumption is expressed by:

$$
\mathrm{b}_{\text {ecombi }}=\mathrm{b}_{\mathrm{eD}} \cdot \frac{1}{\left(1+\frac{\mathrm{N}_{\mathrm{PT}}}{\mathrm{N}_{\mathrm{D}}}+\frac{\mathrm{N}_{\mathrm{ST}}}{\mathrm{N}_{\mathrm{D}}}\right)}[\mathrm{g} / \mathrm{kWh}]
$$

where:

$\eta_{D}, b_{e D}$ - main engine's efficiency and its specific fuel oil consumption, respectively.

From the relations (2) and (3) yields that every additional power in the power system makes the system's efficiency higher and in consequence the specific fuel oil consumption lower. The higher power values achieved from utilization of waste heat contained in exhaust gas from main engine, the lower specific fuel oil consumption, therefore as large as possible output power values should be obtained from both the gas power turbine and steam turbine. Worth mentioning that ouput of gas power turbine depends to a large extent on turbocharger's efficiency - hence a greater amount of exhaust gas can be decompressed in the gas power turbine (increasing its power) - as well as on efficiency of the gas power turbine itself. In steam turbine its power depends to a large extent on selection of live steam parameters as well as condenser parameters.

\section{Variants of combined ship power systems}

Depending on an assumed concept of combined system, systems consisted either of main engine and steam turbine, or main engine, gas turbine and steam turbine, can be considered. Contemporary design solutions of piston engine turbochargers require not very large amount of exhaust gas (due to their high efficiency). In such cases to apply the combined systems consisted of diesel engine, gas power turbine and steam turbine, is possible. This paper describes a combined power plant consisted of a piston combustion engine (serving as main engine) and a steam turbine subsystem.

\section{SELECTION OF MAIN ENGINE AND PRELIMINARY DESIGN ASSUMPTIONS FOR THE COMBINED SHIP POWER SYSTEM}

A 9RTA-96C Wärtsilä Sulzer slow-speed, two-stroke engine was assumed for calculations of the combined power system. The printout of its data calculated by means of the winGTD software [7] achieved from the engine's producer, is presented in Tab. 1.

For the so selected main engine the calculations of the combined system were carried out for tropical operation conditions on two main engine load levels (according to Tab. 1), i.e. $100 \%$ and $90 \%$ CMCR (Contract Maximum Continuous

\begin{tabular}{|c|c|c|c|c|c|c|c|}
\hline $\begin{array}{c}\mathrm{N}_{\mathrm{D}} \\
{[\% \mathrm{CMCR}]}\end{array}$ & $\begin{array}{c}\mathbf{N}_{\mathrm{D}} \\
{[\mathrm{kW}]}\end{array}$ & $\begin{array}{c}\mathrm{N} \\
{[\mathrm{rpm}]}\end{array}$ & $\begin{array}{c}\mathbf{b}_{\mathrm{eD}} \\
{[\mathrm{g} / \mathbf{k W h}]}\end{array}$ & $\begin{array}{c}b_{g_{\_} D} \\
{[\mathrm{~kg} / \mathbf{k W h}]}\end{array}$ & $\begin{array}{l}\mathbf{t}_{\text {exh_TC }} \\
{\left[{ }^{\circ} \mathbf{C}\right]}\end{array}$ & $\begin{array}{c}\mathbf{m}_{\text {air }} \\
{[\mathrm{kg} / \mathrm{h}]}\end{array}$ & $\begin{array}{c}\mathbf{p}_{\mathrm{D}} \\
{[\mathrm{bar}]}\end{array}$ \\
\hline 100 & 51480 & 102.0 & 174.0 & 7.48 & 314.1 & 379819 & 2.67 \\
\hline 90 & 46332 & 98.5 & 169.8 & 7.72 & 301.1 & 353420 & 2.39 \\
\hline
\end{tabular}
Rating).

Tab. 1. Parameters of 9RTA 96C engine [7] 


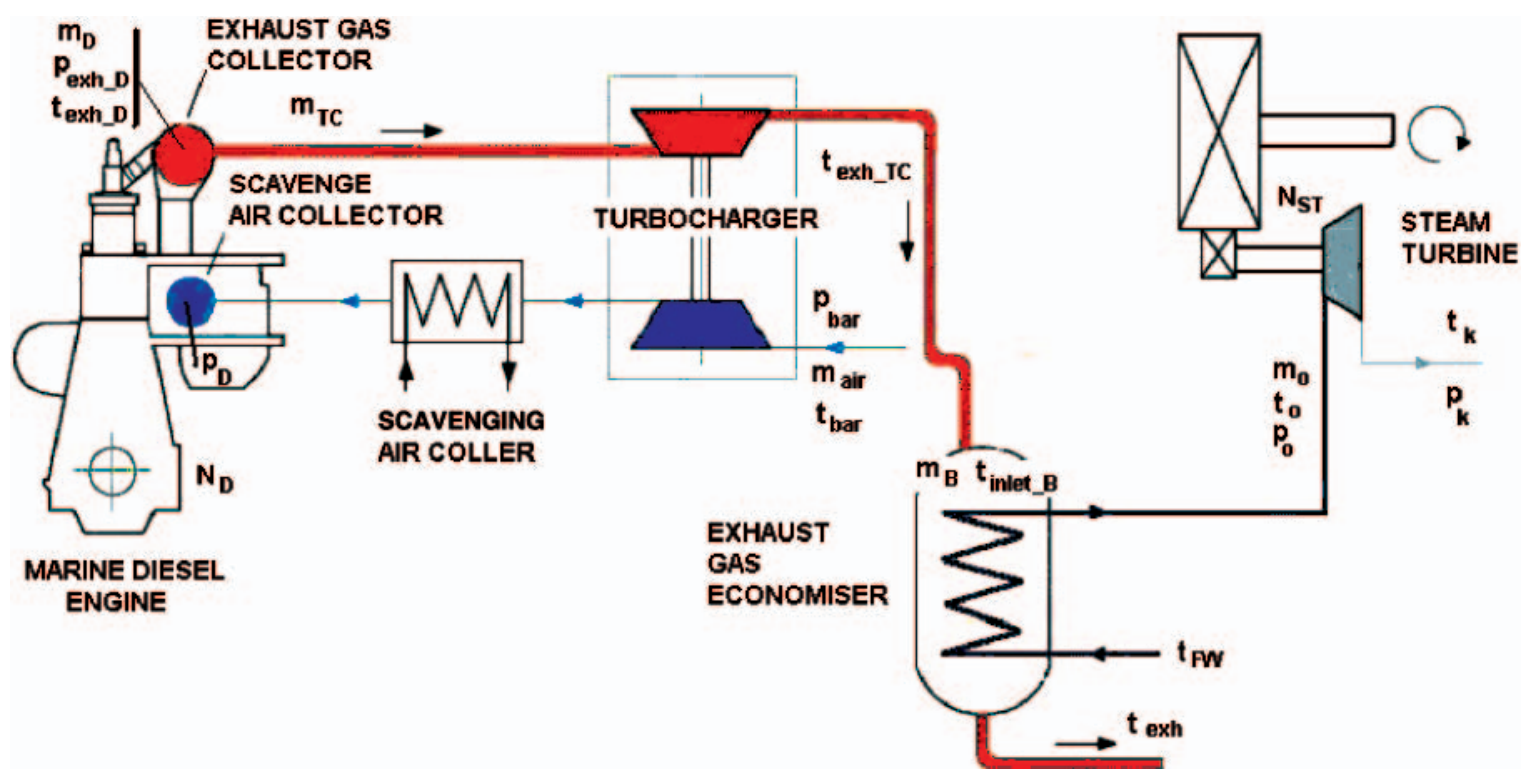

Fig. 2. The ship combined power system consisted of main slow-speed diesel engine and steam turbine (a concept)

\section{THE COMBINED SHIP POWER SYSTEM CONSISTING OF MAIN ENGINE AND STEAM TURBINE SUBSYSTEM}

The combined ship power system assumed for calculations in this section, consisted of the slow-speed piston engine and a steam turbine subsystem utilizing waste heat contained in exhaust gas from the engine, is presented in Fig. 2. Exhaust gas from the main engine turbocharger's turbine flows into the waste heat boiler. The boiler produces the steam for driving the steam turbine which transmits its power to propeller shaft, as well the steam necessary for ship overall purposes. For the so assumed combined system, steam turbine subsystem (cycle) parameters were determined in two calculation points.

\section{CALCULATIONS OF STEAM TURBINE CYCLE}

A two-pressure waste heat boiler was assumed according to [3],[7]. Fig. 3 presents the schematic diagram of steam turbine subsystem with waste heat boiler. Exhaust gas flows from the turbocharger through the waste heat boiler transferring the heat to the steam cycle. In the high-pressure cycle $\left(\mathrm{p}_{\mathrm{II}}\right)$ is produced the overheated live steam of the parameters $\left(\mathrm{p}_{\mathrm{o}}, \mathrm{t}_{\mathrm{o}}\right)$ and mass flux $m$ which supplies the steam turbine. The low-pressure cycle $\left(\mathrm{p}_{\mathrm{I}}\right)$ produces the saturated steam whose one part of $\mathrm{m}_{\mathrm{sS}}$ in amount is extracted for ship overall purposes, and the remaining part is delivered to the steam turbine increasing its power. The applied steam turbine of condensating type additionally drives - through a reduction gear - the ship screw propeller. The assumed deaerating heater of boiling type supplies the water of the temperature $t_{\mathrm{FW}}$ to the waste heat boiler. The condensate $\mathrm{m}_{\mathrm{K}}$ from the condenser and the condensate $\mathrm{m}_{\mathrm{SS}}$ from the cooling box of the subsystem for overall ship purposes flows into the deaerating heater. An additional heat necessary to increase water temperature up to its boiling point in the deaerating heater is taken from the steam turbine's extraction point; the heat is contained in the extracted steam flux $\mathrm{m}_{\mathrm{U}}$. The exhaust gas leaves the waste heat boiler at the temperature $t_{\text {exh }}$.

In each case it was assumed that the overheated live steam temperature at outlet from the boiler is lower than that of flowing-in exhaust gas by $\Delta \mathrm{t}$, i.e.:

$$
\mathrm{t}_{\mathrm{o}}=\mathrm{t}_{\text {inlet_B }}-\Delta \mathrm{t}
$$

The calculations were carried out in function of the pressure $\mathrm{p}_{\mathrm{o}}$ (equal to the $\mathrm{p}_{\mathrm{II}}$ cycle pressure enlarged by hydraulic losses).

$$
\mathrm{p}_{\mathrm{II}}=1.05 \mathrm{p}_{\mathrm{o}}
$$

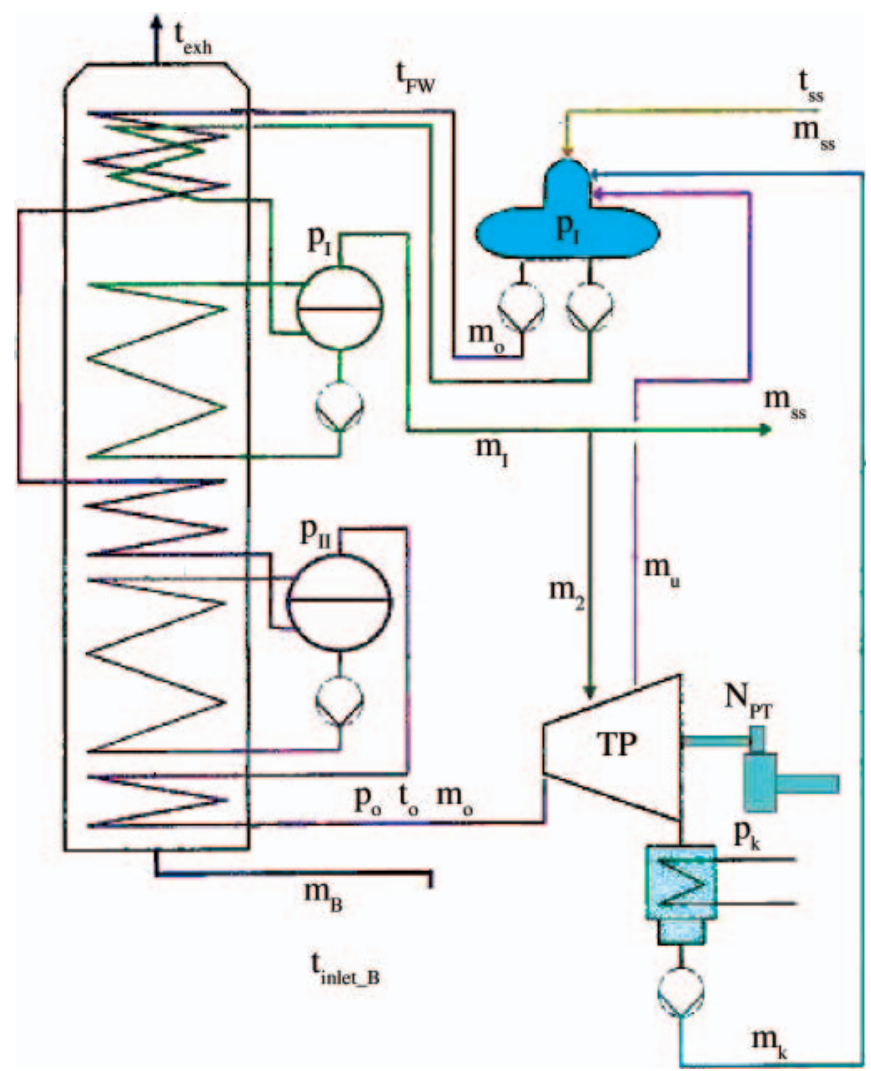

Fig. 3. The schematic diagram of the steam turbine subsystem with waste heat boiler. Note: for explanation of symbols - see Nomenclature

\section{Limitations of parameters and input values assumed for steam turbine cycle calculations}

Limitations of values of steam cycle parameters result from strength, technical and durability conditions of particular elements of the subsystem as well as from design and economical factors. The calculations of the steam subsystem of the ship combined power system were performed under the assumptions and limitations given below. 
The temperature difference between exhaust gas temperature and that of live steam, $\Delta \mathrm{t}$, for waste heat boilers of marine application, was assumed $\Delta \mathrm{t}=15^{\circ} \mathrm{C}$ in compliance with the literature sources $[5,6]$. The value of the ,pitch point" recommended by the firm MAN B\&W [8] for ship boilers is equal to $\delta \mathrm{t}=\delta \mathrm{t}_{1}=\delta \mathrm{t}_{2} \approx 10^{\circ} \mathrm{C}$. The limit steam dryness ratio behind the steam turbine was assumed $\mathrm{x}_{\text {limit }}=0.88$. For ship outboard - water - cooled condensers the firm MAN B\&W [8] recommends to assume the pressure inside the condenser equal to $\mathrm{p}_{\mathrm{k}}=0.065$ bar. Temperature of water supplying the boiler should not be lower than $120^{\circ} \mathrm{C}$, at the sulphur content greater than $2 \%$ [8]. The reason is that outer surface of heater pipes from the exhaust gas side has its temperature higher by $8 \div$ $15^{\circ} \mathrm{C}$ than that of the supply water, and that materials of a higher resistance against acid corrosion are applied; hence for the calculations it was assumed that the supply water temperature can not be lower than $\mathrm{t}_{\mathrm{FW}}>120^{\circ} \mathrm{C}$. It was also assumed that the exhaust gas temperature at outlet from the boiler must be higher by $15^{\circ} \mathrm{C}$ than that of supply water, i.e.: $\mathrm{t}_{\mathrm{exh}}>\mathrm{t}_{\mathrm{FW}}+$ $+15^{\circ} \mathrm{C}$. Every ship combusting the heavy oil for propulsion uses a large amount of heat to prepare the fuel. For the considered containership's power plant the mass steam flow rate for power plant use in compliance with the MAN B\&W recomendations [8] was assumed. The flow rate was made greater by the steam flow rate necessary for ship living purposes, which was estimated to be $m_{\mathrm{ss}}=2000 \mathrm{~kg} / \mathrm{h}$ of saturated steam. According to [8] the steam pressure for living purposes should be kept within the range $\mathrm{p}_{\mathrm{ss}}=7 \div 9$ bar. In the assumed scheme of steam turbine cycle, the pressure of the steam for living purposes is equal to that of the boiler's low-pressure cycle: $p_{\mathrm{I}}=\mathrm{p}_{\mathrm{ss}}$. The temperature in the cooling box was assumed $\mathrm{t}_{\mathrm{ss}}=50^{\circ} \mathrm{C}$, Fig. 3 , in compliance with the recommendation [8].

\section{Steam cycle optimization}

On the basis of the presented algorithm of steam turbine cycle calculations a computer software for determining the cycle parameters with the assumed quantities and limitations, was elaborated. Numerical calculations were carried out in variants, i.e. for:
* the assumed pressure range of high-pressure cycle (of live steam): $p_{o} \in\left\langle p_{o \text { min }}, p_{o \text { max }}\right\rangle$

* the assumed pressure range of the boiler's low-pressure cycle: $p_{1} \in\left\langle p_{1 \text { min }}, p_{1 \text { max }}\right\rangle$

* the assumed pressure in the deaerating heater: $\mathrm{p}_{\mathrm{g}} \in\left\langle\mathrm{p}_{\mathrm{g}_{\_} \min }, \mathrm{p}_{\mathrm{g}_{\_} \max }\right\rangle$.

Optimization of the steam cycle should be so performed as to make use of the heat contained in exhaust gas. Hence it is equivalent to determination of such steam cycle parameters at which the steam turbine reaches its maximum output power. The area of searching for optimum steam cycle parameters, shown in Fig. 4, should be narrowed down to that in which the above assumed limitations imposed on the steam subsystem are satisfied.

The application of the steam subsystem with the waste heat boiler makes output power of the entire power system increasing both at $100 \%$ and $90 \%$ CMCR load of the main engine.

In the Tab. 2 the optimum steam cycle parameters for the two load levels of the high-pressure combustion engine, are presented. The maximum output power of the steam turbine obtained from optimization calculations, equal to $\mathrm{N}_{\text {STmax }}=$ $=3414 \mathrm{~kW}$ for the diesel engine load of $90 \%$, is marked $\Delta$ in Fig. 4. No limitations were taken into account in this case. However in the real system limitations imposed on the steam subsystem should be taken into account. For the assumed limitations, i.e. the narrowed down area of permissible parameters of steam subsystem, the point of the maximum steam cycle output power $\mathrm{N}_{\mathrm{ST} \max }=3182 \mathrm{~kW}$, is marked o. The addition of the steam turbine to the high-pressure combustion engine system resulted in the increase of the power system's output by $\Delta \mathrm{N}_{\mathrm{ST}} / \mathrm{N}_{\mathrm{D}}=+7.43 \%$ and $6.87 \%$ for $100 \%$ and $90 \%$ load, respectively, at the simultaneous decrease of fuel oil consumption in the combined system from $174 \mathrm{~g} / \mathrm{kWh}$ to $162 \mathrm{~g} / \mathrm{kWh}$, and from $169.8 \mathrm{~g} / \mathrm{kWh}$ to $158.9 \mathrm{~g} / \mathrm{kWh}$, respectively, see Tab. 3. The specific fuel oil flux is lowered by $6.91 \%$ for $100 \%$ load and by $6.43 \%$ for $90 \%$ load of the marine diesel engine as compared to those of the marine diesel engine alone. In the combined system its efficiency

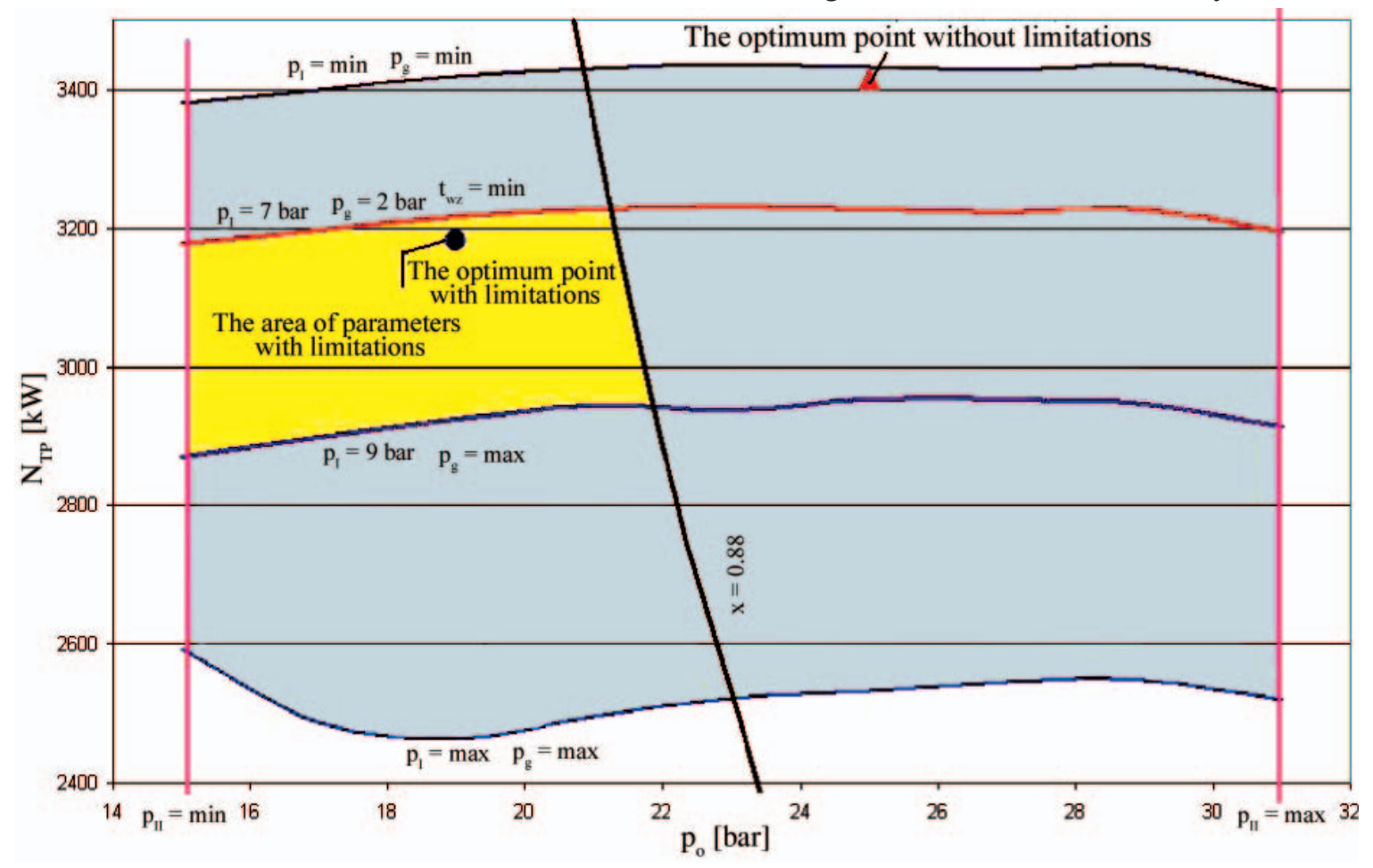

Fig. 4. The permissible area of parameters of the calculated steam cycle 


\begin{tabular}{|c|c|c|c|c|c|c|c|c|c|c|c|c|c|c|}
\hline No. & $\begin{array}{c}\mathbf{N}_{\mathbf{D}} \\
{[\mathbf{\%}]}\end{array}$ & $\begin{array}{c}\mathbf{t}_{\mathbf{o}} \\
{\left[{ }^{\circ} \mathbf{C}\right]}\end{array}$ & $\begin{array}{c}\mathbf{p}_{\mathbf{o}} \\
{[\mathbf{b a r}]}\end{array}$ & $\begin{array}{c}\mathbf{p}_{\mathbf{I}} \\
{[\mathbf{b a r}]}\end{array}$ & $\begin{array}{c}\mathbf{t}_{\mathrm{I}} \\
{\left[{ }^{\circ} \mathbf{C}\right]}\end{array}$ & $\begin{array}{c}\mathbf{p}_{\mathbf{g}} \\
{[\mathbf{b a r}]}\end{array}$ & $\begin{array}{c}\mathbf{t}_{\text {exh }} \\
{\left[{ }^{\circ} \mathbf{C}\right]}\end{array}$ & $\begin{array}{c}\mathbf{t}_{\mathrm{FW}} \\
{\left[{ }^{\circ} \mathbf{C}\right]}\end{array}$ & $\mathbf{x}$ & $\begin{array}{c}\mathbf{m}_{\mathbf{o}} \\
{[\mathbf{t} / \mathbf{h}]}\end{array}$ & $\begin{array}{c}\mathbf{m}_{\mathbf{I}} \\
{[\mathbf{t} / \mathbf{h}]}\end{array}$ & $\begin{array}{c}\mathbf{m}_{\mathrm{u}} \\
{[\mathbf{t} / \mathbf{h}]}\end{array}$ & $\begin{array}{c}\mathbf{N}_{\mathrm{ST}} \\
{[\mathbf{k W}]}\end{array}$ & $\mathbf{N}_{\mathrm{ST}} / \mathbf{N}_{\mathbf{D}}$ \\
\hline $\mathbf{1 0}$ & without limitations \\
\hline $\mathbf{1}$ & 100 & 299 & 27.0 & 7.0 & 165 & 0.50 & 153 & 82 & 0.8715 & 15.02 & 10.78 & 1.93 & 4073 & 0.0791 \\
\hline $\mathbf{2}$ & 90 & 289 & 25.0 & 7.0 & 165 & 0.50 & 154 & 82 & 0.8709 & 12.88 & 9.30 & 1.79 & 3414 & 0.0737 \\
\hline \multicolumn{10}{|c|}{ with limitations } \\
\hline $\mathbf{1}$ & 100 & 299 & 19.0 & 7.0 & 165 & 2.00 & 163 & 121 & 0.8874 & 18.10 & 7.32 & 3.47 & 3823 & 0.0743 \\
\hline $\mathbf{2}$ & 90 & 289 & 19.0 & 7.0 & 165 & 2.00 & 165 & 121 & 0.8830 & 15.02 & 7.15 & 2.86 & 3182 & 0.0687 \\
\hline
\end{tabular}

increased from $49.66 \%$ to $53.06 \%\left(\Delta \eta_{\text {combi }} / \eta_{D}=+7.43 \%\right)$ for $90 \%$ load and from $48.46 \%$ to $52.05 \%\left(\Delta \eta_{\text {combi }} / \eta_{\mathrm{D}}=\right.$ $=+6.87 \%$ ) for $100 \%$ load.

In the steam subsystem with limitations, for e.g. $90 \%$ load, the mass flow rate $\mathrm{m}_{\mathrm{o}}=15.02 \mathrm{t} / \mathrm{h}$ of live overheated steam of the parameters: $\mathrm{t}_{\mathrm{o}}=289^{\circ} \mathrm{C}$ and $\mathrm{p}_{\mathrm{o}}=19 \mathrm{bar}$, and $\mathrm{m}_{\mathrm{t}}=7.15 \mathrm{t} / \mathrm{h}$ of live wet steam of the temperature $\mathrm{t}_{\mathrm{I}}=165^{\circ} \mathrm{C}$ and the pressure $\mathrm{p}_{\mathrm{I}}=7 \mathrm{bar}$, is produced from the heat contained in exhaust gas discharged from the piston engine, see Tab. 2.

\section{THERMODYNAMIC ANALYSIS OF THE COMBINED POWER SYSTEM}

The application of the combined power system to ship propulsion results in the increasing of propulsion system's efficiency and - in consequence - in the lowering of specific fuel oil consumption and - additionally - in the increasing of output power without any additional fuel oil consumption. In Tab. 3 the obtained values of output power, efficiency and fuel oil consumption for the considered ship combined power system with limitations taken into account, are presented.

Tab. 3. Output power, efficiency and specific fuel oil consumption of the combined power system consisted of 9RTA 96C two-stroke diesel engine and steam turbine

\begin{tabular}{|c|c|c|c|c|c|c|}
\hline \multirow{3}{*}{ No. } & \multirow{2}{*}{\multicolumn{2}{|c|}{$\begin{array}{c}\text { ENGINE } \\
\text { RTA96C } \\
N_{D}\end{array}$}} & \multicolumn{2}{|c|}{$\begin{array}{c}\text { STEAM } \\
\text { TURBINE }\end{array}$} & \multicolumn{2}{|c|}{$\begin{array}{c}\text { COMBINED } \\
\text { POWER SYSTEM } \\
\end{array}$} \\
\hline & & & \multirow{2}{*}{$\frac{\mathbf{N}_{\mathrm{ST}}}{[\mathrm{kW}]}$} & \multirow{2}{*}{$\frac{\Delta \mathbf{N}_{\mathrm{ST}} / \mathbf{N}_{\mathrm{D}}}{[\%]}$} & \multirow{2}{*}{$\begin{array}{l}\mathbf{N}_{\text {combi }} \\
{[\mathrm{kW}]}\end{array}$} & \multirow{2}{*}{$\frac{\mathbf{N}_{\text {combi }} / \mathbf{N}_{\mathbf{D}}}{[\%]}$} \\
\hline & {$[\%]$} & {$[\mathrm{kW}]$} & & & & \\
\hline 1 & 100 & 51480 & 3823 & 7.43 & 55303 & 107.43 \\
\hline 2 & 90 & 46332 & 3182 & 6.87 & 49514 & 106.87 \\
\hline \multirow{2}{*}{ No. } & $\mathbf{N}_{\mathrm{D}}$ & $\mathbf{b}_{\mathrm{eD}}$ & & & $\mathbf{b}_{\text {e combi }}$ & $\Delta \mathbf{b}_{\text {e combi }} / \mathbf{b}_{\mathrm{eD}}$ \\
\hline & [\%] & {$[g / k W h]$} & & & [g/kWh] & [\%] \\
\hline 1 & 100 & 174.0 & & & 162.0 & -6.91 \\
\hline 2 & 90 & 169.8 & & & 158.9 & -6.43 \\
\hline \multirow{2}{*}{ No. } & $\mathbf{N}_{\mathrm{D}}$ & $\eta_{D}$ & & & $\eta_{\text {combi }}$ & $\Delta \boldsymbol{\eta}_{\text {combi }} / \boldsymbol{\eta}_{\mathrm{D}}$ \\
\hline & {$[\%]$} & [\%] & & & [\%] & [\%] \\
\hline 1 & 100 & 48.46 & & & 52.05 & +7.43 \\
\hline 2 & 90 & 49.66 & & & 53.06 & +6.87 \\
\hline
\end{tabular}

\section{CONCLUSIONS}

The proposed concept of the ship combined power plant consisted of slow-speed piston engine and additional steam turbine which uses the heat contained in exhaust gas from the piston engine, makes it possible to lower its specific fuel oil consumption by about $6.4 \%$.

O Additionally, without any change of main engine power output the whole power plant output can be increased by about $7 \%$ due to utilization of the heat contained in exhaust gas.

O 9RTA96C diesel engine consumes $205 \mathrm{t}$ /day of fuel oil at $96 \%$ CMCR power output, and in the case of application of the combined power plant the same power output is obtained at $90 \%$ CMCR load of main engine and the specific fuel oil consumption of $189 \mathrm{t} /$ day. This way the shipowner obtains measurable profits in the lowering of the fuel oil consumption by $16 \mathrm{t} /$ day, i.e. $7.8 \%$ savings in the daily fuel oil consumption.

O Application of the additional steam turbine subsystem makes it possible to utilize waste heat from exhaust gas and in consequence to increase ship power plant output at a lower fuel oil consumption, and a lower emission of $\mathrm{NO}_{x}, \mathrm{CO}_{2}$ and $\mathrm{SO}_{x}$ compounds to the atmosphere without any additonal efforts.

\section{NOMENCLATURE}

$\mathrm{b}_{\mathrm{e}} \quad$ - specific fuel oil consumption

$c_{g}, c_{a} \quad-$ specific heat of exhaust gas and air, respectively

$i^{g} \quad-$ specific enthalpy

$\mathrm{m} \quad$ - mass flux of a medium

$\mathrm{N} \quad$ - power

$\mathrm{p} \quad$ - pressure

$\mathrm{T}, \mathrm{t} \quad$ - temperature

$\mathrm{Wu} \quad$ - calorific value of fuel oil

$\eta \quad$ - efficiency

$\kappa_{\mathrm{g}}, \kappa_{\mathrm{a}} \quad$ - isentropic exponent of exhaust gas and air, respectively

\section{Indices}

bar - barometric conditions

B - boiler

combi - combined system

D - marine diesel engine, supercharging

f - fuel

inlet - inlet passage

$\mathrm{k} \quad$ - parameters in a condenser

o - live steam, calculation point

air - air

ss - ship living purposes

$\pi \quad$ - stage of: compression in a compressor, decompression

in a turbine

- compressor

- exhaust gas 


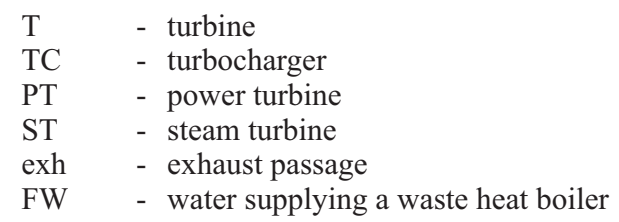

\section{BIBLIOGRAPHY}

1. A new turbocharger generation. ABB Turbo Systems Ltd. Publication No. CH-Z 2035 98E

2. Description of Marine GenSet- Type L28/32H. MAN B\&W Diesel A/S. November 1993

3. Dzida M., Domachowski Z.: A combined gas-steam system in ship electric power system - prospects for large passenger liners (in Polish). In: [Materials of] 8th International Symposium on Ship Power Plants, Szczecin Maritime Academy, Szczecin 1997 4. ISO 8L17: Net specific energy of marine fuels. 1987
5. Kehlhofer R.: Combined-Cycle Gas \& Steam Turbine Power Plants. The Fairmont Press, INC. USA 1991

6. Schrott K. H.: The New Generation of MAN B\&W

Turbochargers. MAN B\&W Publication S.A. 236 5581E. 1995

7. Sulzer RTA 96C. Engine Selection and Project Manual. Wärtsilä, June 2001

8. The MC Engine. Exhaust Gas Date. Waste Heat Recovery System. Total Economy. Publication of MAN B\&W. October 1985.

\section{CONTACT WITH THE AUTHOR}

Marek Dzida, Assoc. Prof.

Faculty of Ocean Engineering and Ship Technology

Gdansk University of Technology

Narutowicza 11/12

80-233 Gdansk, POLAND

e-mail: dzida@pg.gda.pl

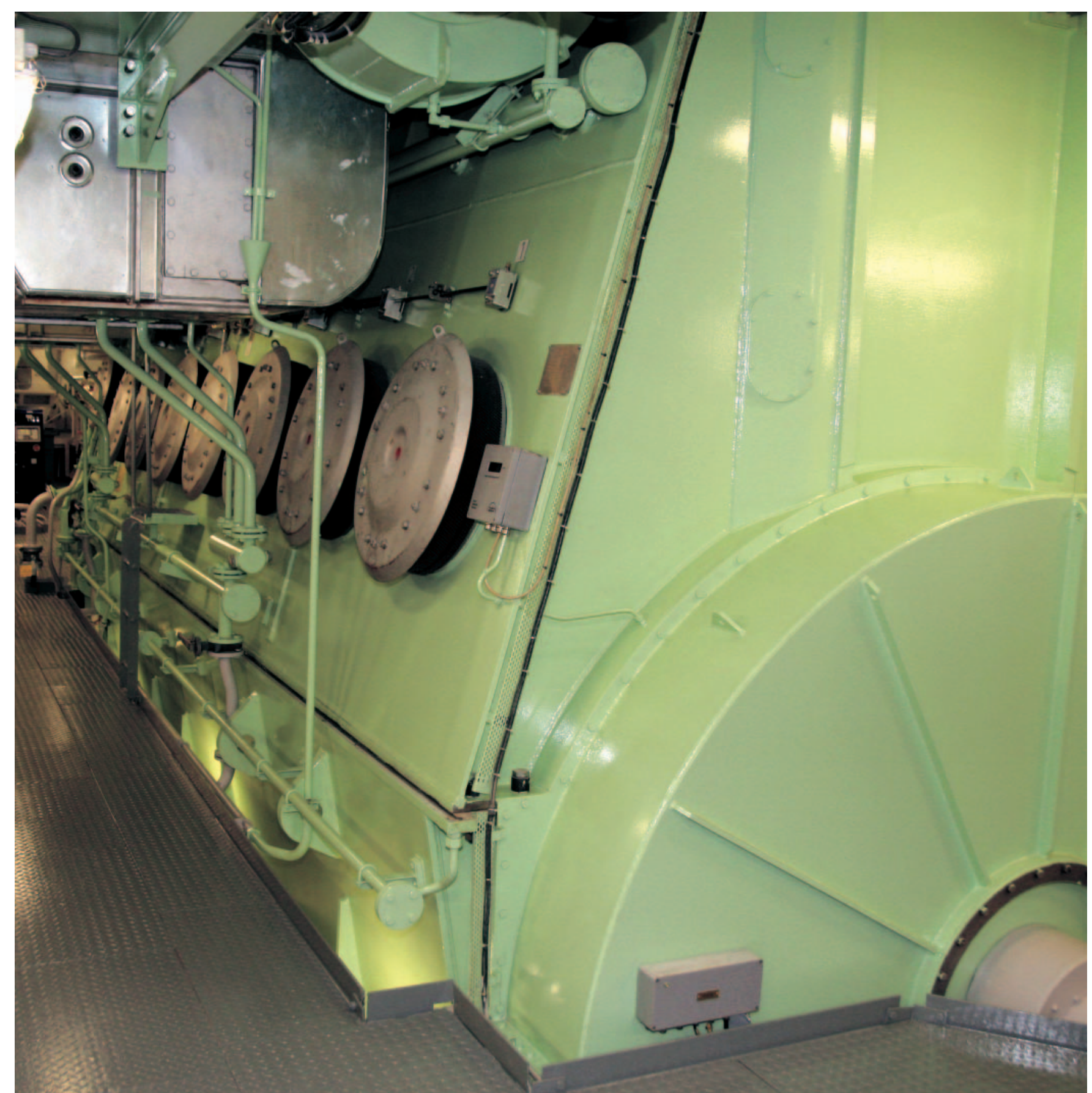

